\title{
CEO Duality and Firm Performance: \\ The Moderating Roles of CEO Informal Power and Board Involvements
}

\begin{abstract}
Purpose: This study draws on the resource dependence theory to synthesize the conflicting arguments as well as commonalities of the agency and stewardship perspectives on the relationship between CEO duality and firm performance.

Design/methodology/approach: Multiple regression analysis is used to analyze the data collected from a sample of 212 large scale publicly listed companies representing 20 sectors in the Colombo Stock Exchange in Sri Lanka.

Research Findings/Insights: Results show, in support of agency theory, that CEO duality exerts a negative effect on firm performance when the CEO is equipped with additional informal power. Conversely, CEO duality exhibits a positive effect on firm performance when board involvements are high, a finding that supports the commonalities of the resource dependence and stewardship theoretical perspectives. Theoretical/Academic Implications: Our study expands the theoretical underpinning of corporate governance research by identifying the performance implications of CEO duality within the broad context of the resource provision of the board of directors and the informal power of CEOs.

Practitioner/Policy Implications: By examining the governance practices and concepts in an Asian developing economy, our study provides insight into the power dynamics between the CEO and the board of directors in managerial contexts that are largely different from those in Western countries.
\end{abstract}

Keywords: CEO duality, Board involvements, CEO informal power, Resource dependence theory

Paper type: Research paper 


\section{Introduction}

CEO duality, a situation in which one person holds both the CEO and the Chairman positions, has become an alarming issue following the recent failures of corporate giants in the early 2000s (Aktas et al., 2018; Duru et al., 2016; Krause et al., 2014; Yang and Zhao, 2014). Interestingly, among ten business giants that were confronted with corporate scandals, eight had CEO duality. While this finding has given the term a negative connotation, there is no consensus among researchers on how to interpret the evidence. Instead, largely due to contradictory assumptions underlying the agency and stewardship perspectives, the effect of CEO duality or non-duality on firm performance has been controversial both in academia and practice (e.g., Aktas et al., 2018; Krause et al., 2014; Boyd, 1995; Finkelstein and D'Aveni, 1994).

Overall, the empirical evidence on the relationship of CEO duality and firm performance has proven inconclusive (e.g., Duru et al., 2016; Yang and Zhao, 2014). Boyd (1995) summarized seven prominent corporate governance studies and realized that only two showed a negative impact whereas the other five showed positive or insignificant effects. Harris and Helfat (1998) found that out of thirteen researches, only three indicated negative effects while ten exhibited either positive or no effects. In addition, a substantial body of literature demonstrated that CEO duality is insignificantly related to firm performance (e.g., Benz and Frey, 2007; Daily and Dalton, 1992; Dalton et al., 1999).

These findings reveal that "both agency theory (in favor of CEO non-duality 
structure) and stewardship theory (in support of CEO duality structure) may be (only) valid under certain conditions" and that "existing theories might need to be treated as complementary viewpoints, each of which draws upon a part of the whole picture" (Elsayed, 2010, p. 80). Accordingly, an examination of the contexts where the concerns of both agency and stewardship theories can be identified becomes valuable.

With the exception of a few studies (e.g., Boyd, 1995; Finkelstein and D'Aveni, 1994), the literature thus far has paid little attention to contextual factors that may help explain inconsistent results stemming from the conflict between the agency and stewardship theories (Kim et al., 2009). A criticism of previous research is that its primary concern is "measuring the effect of duality on performance," rather than "building a theoretical basis for understanding this relationship" (Boyd, 1995, p. 302). Another observation is that corporate governance research can be advanced when potentially contradictory theories can be simultaneously examined under specific contexts (Finkelstein and D'Aveni, 1994). The research also can be advanced when contingent factors that may interact with CEO duality and thus exercise influence on firm outcomes can be identified (Elsayed, 2010; Kim et al., 2009; Krause et al., 2014; Muth and Donaldson, 1998).

To examine the moderating influence of contextual factors on the performance implications of CEO duality, we turn to the resource dependence theory which focuses on the relative power of the CEO and the power dynamics between the CEO and the board of directors (e.g., Krause et al., 2015; Lynall et al., 2003). Research has suggested 
that the resource dependence perspective is advantageous for understanding the contingency contexts of boards and agency issues (Hillman et al., 2009).

To explore the relative power of the CEO, we focus on CEO informal power because it is an essential, yet underexplored, factor that can strengthen the effects of CEO duality (Finkelstein and D'Aveni, 1994). To examine the power dynamics between the CEO and the board of directors, we highlight the role of various board involvements, since a focus on the resource provisions of the board balances the emphasis of previous studies on its monitoring role (Daily et al., 2003; Krause et al., 2015)). Indeed, due to the limited results obtained from the agency theory, research has suggested that "rather than focusing predominantly on directors' willingness or ability to control executives, in future research scholars may yield more productive results by focusing on the assistance directors provide in bringing valued resources to the firm and in serving as a source of advice and counsel for CEOs"' (Hillam et al., 2009, p. 1410).

To further characterize the informal power of CEOs, we highlight their family ties, a critical business concern in the Eastern context (Corbetta and Salvato, 2004), and their participation in board subcommittees, a widely-recognized Western governance issue (Jackling and Johl, 2009). Prior research has proposed the need to identify such additional involvement, including CEO "appointments," as potential sources of power (Greve and Mitsuhashi, 2007, p. 1216). Our study responds to this call, in part, by focusing on family control, a common business practice especially in the Asian context. CEOs with family ties have managerial and symbolic roles that contribute to 
their implicit and explicit power over the board, and allow them considerable freedom to set their own agenda and decide on resource allocations and strategic decisions (Finkelstein and Hambrick, 1989). In addition, our study also considers their membership in subcommittees, since this involvement can directly advance their influence over board decisions. A CEO who holds a position on the board will possess more power through interacting with internal and external actors (cf., Finkelstein and D'Aveni, 1994). Research has also shown that a CEO's multiple board appointments can affect a firm's value (Ferris et al., 2003; Harris and Shimizu, 2004).

As to board involvements, we evaluate the board's shareholdings (Kim et al., 2009) and frequency of board meetings (Jackling and Johl, 2009; Vafeas, 1999) because these factors explicate the degree to which boards are motivated to participate in business operations. Prior studies have recognized the importance of board vigilance (Finkelstein and D'Aveni, 1994) and board shareholdings (Kim et al., 2009). A board with a great number of shares in a company has significant interests in the firm and thus is more likely to perform a vigilant role (Finkelstein and Hambrick, 1989). In addition, the frequency of board meetings can influence a firm's resource capacity and ultimately its financial performance by expanding the cognitive bases of CEOs and extending the advice and counsel channels of the firm (cf., Smith et al., 1994). Thus, a significant indicator of board activities is the frequency of board meetings (Vafeas, 1999).

In a nutshell, this study aims to integrate the resource dependence perspective with the agency and stewardship theories in order to identify the contexts where CEO 
duality may advance or diminish firm performance. Such a multitheoretic approach recognizes the conflicting as well as "the commonalities of the theoretical perspectives," and further suggests that agency concerns can be interpreted by board practices (Lynall et al., 2003, p. 428) and CEO informal power (Boyd, 1995).

To examine these issues, we collected data from 212 publicly-listed firms in Sri Lanka. The examination of corporate governance issues in a non-Western country is important, because "the underlying conditions for companies to adhere with good corporate governance principles vary with institutional and country differences" (Holm and Scholer, 2010, pp. 32-33). Moreover, the recognition of contextual factors in CEO duality research is especially promising in the Asian context, because "the process by which the CEO affects firm performance has not yet been addressed in the literature" (Bruton and Lau, 2008, p. 654). Interestingly, few studies which have been carried out in the Sri Lankan context investigating this phenomenon have also arrived conflicting findings. For instance, although Azeez (2015) revealed that the separation of the two posts of CEO and chairman has a significant positive relationship with the firm performance, Dharmadasa et al. (2014) found no significant relationship between these two variables.

Our study expands the theoretical underpinning of corporate governance research by identifying the performance implications of CEO duality within the broad context of the board of directors' ability to provide resources and the CEO's informal power. By examining the theory and practice of corporate governance in a developing economy, the study also advances the generalizability of governance research (Bruton 
and Lau, 2008; McCarthy and Puffer, 2008).

The remainder of the paper is organized as follows. The next section discusses the theoretical background and literature review. Section three proposes hypotheses of the study. Section four discusses the methods followed by the results presented in the section five. The final section concludes the paper by highlighting the theoretical and practical contribution, and directions for future research.

\section{Theoretical Background}

Research has proposed that neither agency nor stewardship theory can clearly determine the outcomes of CEO duality (Boyd, 1995). Moreover, both agency and stewardship theories overlook the dynamic nature of corporate governance and thus fail to reveal the underlying governance mechanisms (Elsayed, 2010). Our study intends to fill these gaps by employing the resource dependence theory to explore moderating mechanisms on the effects of CEO duality, and thus synthesize the findings of these two theoretical perspectives.

\subsection{Agency Theory and the Need for Complementary Perspectives}

The agency theory argues that separating the CEO and chairman positions enhances the transparency and accountability of firm decisions, which increases shareholders' trust and ultimately firm performance (Adams et al., 2005; Gillan, 2006; Kroll et al., 2008). This perspective favors CEO non-duality because a dual-position CEO may become a "self-serving, economically rational" person (Corbetta and Salvato, 2004, p. 357), especially when the CEO has family ties or board committee 
appointments. In this regard, it is worthwhile noting that, while there may be many reasons for a firm to choose CEO duality, no evidence thus far shows that CEO duality is intentionally designed with the purpose of optimizing firm performance (Iyengar and Zampelli, 2009). Under circumstances in which CEO duality is present, the agency perspective relies heavily on the monitoring functions of board of directors and expects the board to mitigate the potentially negative effects of power imbalance (Finkelstein and D'Aveni, 1994).

Notwithstanding the potential for managerial abuse under CEO duality, such a negative interpretation of duality has been questioned because business practices and empirical findings show that such abuses tend not to occur, or their occurrence cannot be presumed. In fact, duality may encourage a CEO to be a "self actualizing, collective serving" person (Corbetta and Salvato, 2004, p. 357; Boyd, 1995). Thus, the quest for integrating other theories into the agency perspective to explain the impact of CEO duality on firm performance has gained momentum. Davis et al. (1997, p. 20-21) have proposed that "although agency theory addresses manager-principal interest divergence, additional theory is needed to explain what, if anything, causes interests to be aligned." In addition, Corbetta and Salvato (2004, p. 356) suggest that, although agency theory is a suitable mechanism for illustrating organizational relationships in efficient ways, "what is missing is a conceptual lens to explain behaviors aimed at maximizing potential performance within organizations in which a proorganizational attitude coexists with self-serving motives." An integrated consideration of agency theory and other perspectives, such as the well-recognized 
stewardship and resource dependence theories, can help explain previous opposing results and expand the applicability of the agency theory (Dalton et al., 2003).

The adoption of agency theory can be justified by the features of institutional and regulatory framework within which the companies govern in Sri Lanka. For instance, it has a properly laid down system which promotes private sector investments through the Colombo Stock Exchange. Further, the Companies Act and the other regulations, and codes of corporate governance in Sri Lanka are largely based on those of international laws, regulations and codes of best practice in corporate governance (Wijethilake et al., 2015). Furthermore, Sri Lanka was a colony from the early $16^{\text {th }}$ century until 1948, when it gained independence from the British. Hence, corporate governance in Sri Lanka have been closely associated with the colonial ties and economic spheres (Ekanayake, 2011). For example, most of the laws and regulations related to the governing of companies are based on those of the British.

On the other hand, nature of the ownership of the companies in Sri Lanka supports the adoption of the stewardship theory. For instance, a considerable number of Sri Lankan companies have family ties and concentrated share ownerships (Wijethilake et al., 2015). This could influence the informal power of the CEO, and the involvement of the board via larger shareholdings.

\subsection{An Evaluation of the Stewardship Theory}


Contrary to the conceptualizations of agency theory, stewardship theory defines situations where executives are not concerned for their own interests, but rather behave as stewards in advancing the benefits of the entire organization (Davis et al., 1997). While agency theory promotes a control-oriented perspective, an involvementoriented standpoint encourages empowerment, decentralised decision making and interactive management style (Davis et al., 1997; Van Thiel, 2016). More specifically, stewardship theory emphasises on practices and processes that enable and inspire instead of monitoring and controlling.

As per the conflicting opinion suggested by the stewardship theory, which establishes that the integration of the CEO and chairman roles would improve performance, CEO duality is a positive instrument to exploit firm information in an effective way as the CEO is well conscious of organisational functions (Davis, Schoorman, \& Donaldson, 1997; Donaldson \& Davis, 1991). This distinctive feature is an answer in settings where information asymmetry arises between the CEO and the chairman. This perspective proposes that CEO duality can "facilitate effective action by the CEO, and consequently lead to higher performance" (Boyd, 1995, p. 304). Proponents of the stewardship theory also maintain that goal alignment and trustworthiness between principal and agent considerably decreases the potential of selfish conduct. Accordingly, this minimizes forceful supervising, which may be observed as an indication of mistrust, resulting resistance between principal and agent (Van Thiel, 2016).

Here again, a number of scholars have expressed serious reservations about these 
arguments. A fairly recent study has maintained that "stewardship and stakeholder theory remove some restrictive assumptions of the agency approach, yet do not provide a comprehensive research framework that links corporate governance with the broader context of different organizational environments" (Agruilera et al., 2008, p. 478). Because CEO duality and non-duality do not show significant differences in long-term firm performance, an oblique favor of duality is largely inadequate (Baliga et al., 1996). Instead, identifying the contexts where stewardship or agency perspective can function well is potentially more insightful (Eddleston and Kellermanns, 2007). Chrisman (2019) argues that although the stewardship theory is used as an alternative to agency theory, the theory does not provide clear presumptions on bounded rationality and pre employment scenarios as neglect of such mattes decreases its realism and relevance. Accordingly, underlying assumptions of stewardship theory should to be revisited to increase its realism and relevance (Chrisman, 2019).

\subsection{The Role of the Resource Dependence Theory}

The foregoing discussion of CEO duality does not go so far as to determine the actual situations in which specific theories might apply; rather, it outlines mixed results that stem from conflicting theories. Thus, our study addresses the resource dependence theory to explicate the dynamics between the CEO and the board of directors in an attempt to shed light on the different contexts in which specific theories might function to advantage. 
Research has shown that, although resource dependence theory is "less commonly used to study boards than agency theory, empirical evidence to date suggests that it is a more successful lens for understanding boards" (Hillman et al., 2009, p. 1408). The advantage of resource dependence theory pertains to its ability to help "illuminate boards' composition in both the collective and formalization stages of the organizational life cycle, when CEOs have dominant power" (Lynall et al., 2003, p. 427). In contrast to the agency perspective, the resource dependence theory proposes that resource provision, rather than monitoring, is the key function of a board (Hillman and Dalziel, 2003; Krause et al., 2016). Corporate boards are chosen “to maximize the provision of important resources to the firm" and each director is expected to "bring different linkages and resources to a board" (Lynall et al., 2003, p. 418). Accordingly, the frequency of board meetings and directors' equity holdings can be considered as a resource provision, rather than actions of scrutiny and enforcement (Dalton et al., 2003). Similarly, a CEO with informal power such as family relationships and board committee appointments may expand a company's network and cognitive resources and thus become an impetus of the firm (cf., Eddleston and Kellermanns, 2007).

While the resource dependence theory has been the dominant approach to understand the existence of active boards for many years (Pfeffer and Salancik, 1978), it is acknowledged that more recently the social network theory has supplemented the contribution of resource dependence theory (Westphal, 1999; Carpenter and 
Westphal, 2001). Social network theory recognizes important board roles as networking, cohesion and exchange of information, door-opening, legitimacy, and communication in internal relations (Gulati and Westphal, 1999; Westphal, 1999; Carpenter and Westphal, 2001).

As the resource dependence theory views the board as an administrative body that connects the organisation and with its external environment, this approach is more suitable to understand the board behaviour in the Sri Lankan context as compared to social network theory. In particular, this is important given the nature of Sri Lankan national and business culture mainly dominated by Asian values and beliefs, and the emerging nature of most of the business establishments. Further, viewing the board's role from the resource dependence perspective can be rationalized as it reduces organization's reliance on external stakeholders or help to defend the organisation from various external pressures.

\section{Hypotheses}

The effect of CEO duality on firm performance remains inconclusive. Our study intends to shed light on the conflicting results by examining the moderating effects of CEO informal power and various board involvements.

\subsection{Moderating Effects of CEO Informal Power}

The informal power of executives is not "necessarily associated with formal structure" (Peiro and Melia, 2003, p. 19). Research has shown that the power of CEOs generated from informal mechanisms plays the most significant role among the factors that 
contribute to firm performance (Finkelstein and D'Aveni, 1994).

\subsection{CEOs with family ties}

Family ties refer to appointments in which the appointment member is related to the founder of the firm or acts as a representative of family share ownerships (Anderson et al., 2003). Finkelstein (1992) posited that executives who are closely related to the founder can exercise control over the board. Again, Barkema and Pennings (1998) found that when CEOs have informal power acquired through family ties, they have greater opportunities to dominate the board. They can also affect the composition of board members (Lynall et al., 2003) and thus shrunk the board's monitoring process. Consequently, in accordance with the agency perspective, scholars argue that in situations where family ties exist, the greater the CEO duality, the more likely it is that the CEO will shape firm strategies to advance personal interests (Greve and Mitsuhashi, 2007; Beavers, 2017). Supporting this argument is the study of Anderson and Reeb (2004), who found that firms with strong founding-family ownership have considerably worse performance than non-family firms. Bennedsen et al. (2007) also found that family successions of CEO have a large negative causal impact on firm performance. Moreover, Finkelstein and D'Aveni (1994) showed that when CEOs possess more informal power, they tend to build an entrenchment in order to protect their individual interests.

Nonetheless, Mooney et al. (2007) revealed that, compared to the appointment of non-family CEOs whose failure rate could be up to $55 \%$, the failure rate of familyappointed CEOs did not exceed 34\%. Anderson and Reeb (2003) found family firms 
perform better than nonfamily firms. Also, they revealed that when family members serve as CEO, performance is better than with outside CEOs. However, Villalonga and Amit (2006) revealed that family ownership creates value only when the founder serves as CEO of the family firm or as Chairman with a hired CEO (i.e., when descendants serve as CEOs, firm value is destroyed). Anderson et al. (2003) found that founding family ownership leads to a lower cost of debt financing. In contrast to agency theory, the stewardship and resource dependence perspectives indicate that family participation can provide a firm with unique resources such as social capital and interpersonal network - resources that can create value for a firm and ultimately improve financial performance (Eddleston and Kellermanns, 2007). Research has identified family participation as a critical resource of a firm, because it can advance honor and altruism "that encourages family members to place the firm's objectives ahead of their own" (Eddleston and Kellermanns, 2007, p. 547). These results indicate that CEO duality can help a firm achieve better performance when family ties are involved, because family appointed CEOs will consider not only their in-role but also extra-role duties and be motivated to relinquish opportunistic concerns (Davis et al., 1997).

The foregoing arguments have presented different and opposing perspectives on the effect of a CEO's family representation. Accordingly, this study develops the following competing hypotheses.

Hypothesis 1a: As indicated by the agency theory, a CEO's family ties will worsen the relationship between $C E O$ duality and firm performance. 
Hypothesis 1b: As indicated by the stewardship and resource dependence theories, a CEO's family ties will improve the relationship between CEO duality and firm performance.

\subsection{The participation of CEOs in board subcommittees}

The extent to which a CEO can acquire certain power by holding memberships in board committees is identified as CEO busyness (Jackling and Johl, 2009). According to the agency perspective, when dual-appointed CEOs hold more positions, they have more opportunities to dominate the boards and thus diminish the function of the boards (Finkelstein, 1992). A growing body of research has criticized CEOs' board participation, because it can make the decisions of board subcommittees lose transparency and accountability (Finkelstein and D'Aveni, 1994). As this criticism holds, the non-independent pressure of CEOs on independent board decisions can be detrimental to corporate outcomes. Research argued that "CEOs often have access to sources of power that allow them to manipulate their pay at the expense of (other) shareholders," a typical case when a CEO holds more positions on board subcommittees (Barkema and Pennings, 1998, p. 980). Research also supports this view by showing that while duality alone does not have a direct impact on the stock market, once CEO acquires another title in the board, the stock market reacts adversely (Worrell et al., 1998). Further, CEOs with a number of committee appointments need to reallocate their time, which can distract them from routine functions and strategic focus, and lead to poor performance.

Conversely, the stewardship and resource dependence perspectives assert that a dual-position CEO with more board appointments will have more opportunities to 
engage with the external environment, which can create more avenues to access resources and thus increase firm values (cf., Jackling and Johl, 2009). The internal and external networks created through the active involvement of CEOs in board decisions can spontaneously advance their experiences and breadth of perspectives, which then enhance a firm's adaptability (Lynall et al., 2003). Research has shown that directors with multiple appointments have a positive impact on corporate performance (Ferris et al., 2003; Harris and Shimizu, 2004; Masulis and Mobbs, 2011; Masulis and Mobbs, 2014). In a similar vein, the effectiveness of CEOs holding several positions on independent board subcommittees can be advanced because these CEOs tend to view themselves as stewards of firm performance (cf., Barkema and Pennings, 1998).

Hypothesis 2a: As indicated by the agency theory, a CEO's participation in board subcommittees will worsen the relationship between CEO duality and firm performance.

Hypothesis 2b: As indicated by the stewardship and resource dependence theories, a CEO's participation in board subcommittees will improve the relationship between CEO duality and firm performance.

\subsection{Moderating Effects of Board Involvements}

As per the agency theory, the role of the board is to monitor management in order to ensure that shareholders' interests are secured (Shleifer and Vishny, 1997). Accordingly, Finkelstein and D'Aveni (1994) define board vigilance as a motivation and incentive to effectively monitor and discipline CEOs. Their study argues that board vigilance can oversee the risks associated with management and strategic decisions, and thus help a dual-position CEO advance firm performance. A case in point is the Enron scandal and bankruptcy of the Enron corporation, which may have 
been avoided had its board been more agile (Gillan and Martin, 2007). However, greater board control over a CEO's functions can hurt firm performance by adversely affecting the CEO's willingness and motivation to generate strategic options in the focal company (McDonald and Westphal, 2010). Research has suggested that "the greater the power of the board in relation to its existing CEO, the greater the likelihood of change in CEO characteristics when succession occurs" (Zajac and Westphal, 1996, p. 69). It follows that when the efficiency of the board's involvement outweighs the agency cost brought by opportunistic behaviors, the adverse effect of CEO duality on firm performance, as proposed by agency theory, will be altered. The focus on the power dynamics between the CEO and the board, as advocated by the resource dependence theory, can look into the effectiveness of CEO duality from both the controlling and collaborative viewpoints (Sundaramurthy and Lewis, 2003), and thus synthesize the agency and stewardship perspectives.

\subsection{Board Shareholdings}

A board with high equity ownership will be greatly motivated to get involved in the company's decisions and help build a firewall to reject actions that may hurt firm performance (Kim et al., 2009). Finkelstein and D'Aveni (1994) maintain that a nonshareholding board tends to allow its CEO to make firm decisions based on individual initiatives. Conversely, boards with a large shareholding will closely monitor the agenda-setting of CEOs and take appropriate measures to protect the interests of shareholders, which ultimately will affect the duality or non-duality structure of the CEO position (Elsayed, 2010). Board ownership is also an indication of the level of 
stewardship toward the firm. Sundaramurthy and Lewis (2003, p. 398) highlight the prominence of equity ownership among executives and the board in promoting firm performance. They reason that executive ownership "reduces goal conflicts and avoids increasing risk differentials," while it also "fosters firm identifications and long term relations." A board with minority equity holdings is less likely to monitor CEO's opportunistic behaviors, which will then incline toward the pursuit of personal interests at the expenses of shareholders' benefits (Lasfer, 2006; Hoskisson et al., 2002).

To summarize the arguments that have been made, we propose that a board with a high level of ownership will be more motivated to exercise its role in monitoring management and providing resources to the firm. Consequently, regardless of whether the issue is considered from the agency or stewardship perspective, we expect board shareholdings to drive CEO duality in a direction that advances firm value.

Hypothesis 3: Board shareholdings will positively moderate the relationship between CEO duality and firm performance. Specifically, the relationship between CEO duality and firm performance will be improved when board shareholdings are high.

\subsection{Frequency of Board Meetings}

Among board activities, board meetings play a significant role because they allow board members to make collective decisions and initiate appropriate measures to implement strategic decisions and thereby mitigate CEO dominance. The resource dependence theory asserts that frequent board meetings can prompt the board to exercise its functions in relation to corporate activities and provide the board with a mechanism to correct potentially adverse actions brought by CEO duality (Jackling 
and Johl, 2009). A dual-position CEO may tend to control the board agenda by holding few board meetings (Finkelstein and D'Aveni, 1994). The board of directors can exercise appropriate management control and scrutinize poor performance by holding frequent board meetings and thus increase corporate performance (Jackling and Johl, 2009).

Research has concluded that, by exercising both controlling and collaborative strategies (Sundaramurthy and Lewis, 2003), boards can advance the links between a dual-position $\mathrm{CEO}$ and board members through the frequency of their meetings. In this way, they can also advance the relations between a firm and external stakeholder, and thus increase the firm's information-processing capacity and internal and external social capital (cf., Muth and Donaldson, 1998), all of which can create benefits for the firm.

Hypothesis 4: The frequency of board meetings will positively moderate the relationship between CEO duality and firm performance. Specifically, the relationship between CEO duality and firm performance will be improved when the frequency of board meetings is high.

\section{Methods}

\subsection{Research Design and Sample Selection}

The sample of this study was drawn from publicly-listed companies in the Colombo Stock Exchange (CSE) of Sri Lanka in 2009. As a developing economy in Asia, Sri Lanka provides the corporate governance literature with a different institutional context and thus is expected to add new insights into previous Western-focused 
studies (Bruton and Lau, 2008). All listed corporations in the CSE are required to follow the listed rules and amended corporate governance guidelines introduced by the CSE, Securities and Exchange Commission (SEC), and Institute of Chartered Accountants of Sri Lanka (ICASL). We excluded eighteen firms who were in financial predicament in 2007-2009. Specifically, we excluded those companies that were temporarily delisted in the stock exchange, failed to submit annual reports for a given period of time, lacked sufficient study information, or registered or went bankrupt during our study period.

In total, 212 listed companies were finally selected, representing 100\% of the active firms in the CSE during the fiscal years. The 212 firms were spread over 20 industries. 31 firms (14.6\%) were in banking and finance, 28 (13.21\%) were in hotels and travelling and another $28(31.21 \%)$ were in manufacturing. Average firm age was 29.96 years, while the average number of full-time employees was 1,790 persons. Table 1 illustrates the summary of our firms' industry characteristics.

\section{Insert Table 1 about here}

\subsection{Measures}

Independent and Dependent Variables

CEO duality: Data were collected from the annual reports of the publicly-listed companies in the $2008 / 2009$ fiscal year. CEO duality is a binary variable; a firm with duality was coded " 1 " while non-duality was coded "0" (Boyd, 1995; Finkelstein and 
D’Aveni, 1994).

Earnings per share (EPS): EPS was used to assess firm performance because it can largely explain the functions performed by executives and boards. Previous research has used this measure to examine the effect of CEO duality on firm performance (Iyengar and Zampelli, 2009).

\section{Moderating Variables}

CEO informal power: Family ties and participation in board subcommittees were used to capture CEO informal power. We measured the family ties of CEOs by whether the CEO was a family member or relative of the founder with same last name or family name (Finkelstein, 1992). If the CEO was a family member, code "1" was assigned, and otherwise code "0." Participation in board subcommittees was assessed by a CEO's membership representation in audit, nomination, or remuneration committees (Finkelstein and D'Aveni, 1994; Jackling and Johl, 2009). If a CEO participated in one of these subcommittees, code " 1 " was assigned; otherwise, it was code " 0. "

Board involvements: Board shareholdings and the frequency of board meetings were used to evaluate board involvements. The former was measured by the percentage of a board's total shares divided by the company's outstanding shares (Kim et al., 2009). The frequency of board meetings was measured by the number of board meetings held during the 2008/2009 financial year (Jackling and Johl, 2009). 
To guard against spurious results, several executive-level and firm-level variables were also controlled in the model. The evaluation of executive-level controls included CEO tenure and the number of board members, board subcommittees, and executive team members. CEO tenure was measured as the number of years that a CEO was employed by the firm (Kim et al., 2009). Research has shown that long-tenure CEOs are more likely to have poor performance (Berrone and Gomez-Mejia, 2009). The number of board members, including independent, non-executive, and executive directors, was also controlled in order to avoid the bias presented by the influence of different types of directors on the informal power and decision making of CEOs. Moreover, from the boards' viewpoint, controlling these variables allowed a distinction to be made between the resource provision of the board and its monitoring and controlling activities (Henry, 2009; McDonald and Westphal, 2010). The number of independent directors was calculated as the total number of outside directors (Finkelstein and D'Aveni, 1994). To avoid the influence of the chairman's busyness on CEO duality and CEO busyness, we controlled for the former by taking into account the chairman's multi-directorships in board subcommittees. The number of board subcommittees was also controlled, because it may confound the effects of the frequency of board meetings. The availability of board subcommittees was measured as the total of audit, remuneration, and nomination committees that were reported under the governance statement in the annual report (Reeb and Upadhyay, 2010). Finally, the number of executive team members (i.e., executive team size), including CEO and senior executives who report directly to the CEO, was controlled because it 
has a significant effect on firm performance (Lin and Shih, 2008).

For firm-level controls, we include firm age, firm size, prior performance, firm slack, and industry segments. Firm age and firm size, which captured organizational maturity (Matta and Beamish, 2008), were calculated as the natural logarithm of a firm's founding years and the number of full-time employees (Ahmed et al., 2006). Prior performance, measured by the natural logarithms of EPS in the $2007 / 2008$ fiscal year, was controlled since it directly influences a CEO's perception of firm performance and the board of directors' involvement (Finkelstein and D' Aveni, 1994; Kim et al., 2009). The logarithmic form of analysis was applied to reduce heteroscedasticity (Finkelstein and D'Aveni, 1994). Firm slack was measured by firm leverage and current ratio, in which leverage was calculated as long-term debt divided by total assets (Ahmed et al., 2006) while current ratio was calculated as current assets divided by current liabilities (Jaggi and Gul, 2001). Finally, industry was controlled by being classified into three segments (i.e., of manufacturing, service and others), since research has shown that CEO duality varies with industry characteristics (Boyd, 1995; Finkelstein and D'Aveni, 1994).

\subsection{Analyses}

A hierarchical regression analysis was applied to examine our theoretically-derived hypotheses. In the first step, control variables were entered into the model. The effect of CEO duality was tested in the second model while moderators were examined in the third model. Finally, the two-way interaction terms were assessed in model four. To test the interaction effects, we mean-centered our independent and moderating 
variables and created four multiplicative terms so as to reduce the likelihood of multicollinearity (Aiken and West, 1991). We also used the variance inflation factor (VIF) to evaluate the effects of multicollinearity. Results showed that VIFs for the independent variables ranged from 1.1 to 4.0 , while for the interaction terms they ranged from 1.2 to 1.7 , indicating that multicollinearity was largely unlikely to bias the regression results. Table 2 presents the descriptive statistics and the intercorrelation coefficients of our variables. Significant correlations between the studied variables provide preliminary evidence for further examinations.

Insert Table 2 about here

\section{Results}

Hypothesis $1 a$ and $1 b$

Table 3 presents the regression results. As shown in model 4, the coefficient for the interaction between duality and family ties is negatively significant $(\beta=-.139, \mathrm{t}=-2.01$, $\mathrm{p}<.05)$. Thus, hypothesis $1 \mathrm{a}$ is supported, and hypothesis $1 \mathrm{~b}$ is unsupported. A CEO's family ties tend to worsen the relationship between CEO duality and firm performance, a result that is consistent with the agency prediction. Figure 1 depicts the interaction plot which supports the interpretation. Consequently, we maintain that it is unwise to appoint a CEO who has family ties to the firm to take the board chair position.

Insert Table 3 about here 
Insert Figure 1 about here

Hypothesis $2 a$ and $2 b$

Model 4 in Table 3 also showed that the coefficient for the interaction between duality and participation in board committees is negatively significant $(\beta=-.141, \mathrm{t}=-2.17, \mathrm{p}<$ .05). Therefore, hypothesis $2 \mathrm{a}$ is supported, and hypothesis $2 \mathrm{~b}$ is unsupported. A CEO who holds positions on board subcommittees will adversely affect the relationship between CEO duality and firm performance, as the agency theory proposes. Figure 2 presents the interaction plot which confirms this prediction. We conclude that the stewardship and resource dependence perspectives are not valid when a dualposition CEO also participates in subcommittees.

Insert Figure 2 about here

Hypothesis 3

Hypothesis 3 predicted that board shareholdings would positively moderate the effect of CEO duality on firm performance. As hypothesized, the interaction term between shareholdings and duality in Model 4 is positively significant $(\beta=.128, \mathrm{t}=2.17, \mathrm{p}<.05)$. As Figure 3 shows, plotting the interactions terms further supports the clarification. Accordingly, this study affirms that the equity holdings of boards of directors can support duality to improve firm performance.

Insert Figure 3 about here

Hypothesis 4

Hypothesis 4 predicted that frequency of board meetings would positively moderate 
the effect of CEO duality on firm performance. As expected, the regression coefficient for the interaction term in Model 4 is positively significant $(\beta=.133, \mathrm{t}=1.94, \mathrm{p}<.10)$, a finding that supports hypothesis 4 . Plotting the interaction terms in Figure 4 depicts this finding. As shown, the frequency of board meetings can support duality to improve firm performance.

Insert Figure 4 about here

\subsection{Post Hoc Checks: Control, Independent, and Moderating Variables}

Although we do not focus on their direct effects, we are interested in the effects of executive-level and firm-level factors on firm performance, especially since our research may be among the first of the few studies in this country that explore various determinants of ultimate firm performance.

Model 1 examined the effects of control variables, which can explain a total of $37 \%$ of the variances in firm performance. CEO tenure, the number of executive and non-executive directors, and debt ratio showed negative effects on firm performance, while executive team size, current ratio, and past performance showed positive effects.

Model 2 tested the direct relationship between CEO duality and firm performance. The result showed that CEO duality has a positive yet insignificant relationship with firm performance $(\beta=.075, \mathrm{t}=1.20)$. Nonetheless, CEO duality positively affected firm performance in Model $3(\beta=.183, \mathrm{t}=1.98, \mathrm{p}>.05)$ and Model 4 
$(\beta=.294, \mathrm{t}=2.72 \mathrm{p}<.01)$ when the moderators were included in the model. These results, combined with the significantly positive effects of board shareholdings and frequency of board meetings in Model 3, revealed that even though CEO duality itself has little impact on firm performance, it can bring value to a firm when the CEO has the resource support of the board of directors.

\section{Discussion}

The central objective of this study was to examine the moderating effects of CEO informal power and board involvements on the relationship between CEO duality and firm performance in an attempt to explain the conflicting as well as the commonalities of the results obtained by the agency and stewardship perspectives. Specifically, we drew on the resource dependence theory to resolve the apparent discrepancy between these two theoretical orientations, thereby eliminating the 'black box' in the dualityperformance relationship.

In line with prior literature, we found that no significant relationship exists between CEO duality and firm performance. Thus, identifying the contexts that can determine the effectiveness of duality or non-duality becomes imperative. In this sense, the literature is correct in maintaining that neither the agency nor stewardship model can properly predict the duality-performance relationship (Boyd, 1995). Nonetheless, an examination of this relationship from a contingency perspective can bring significant insights to the issue regarding CEO duality and corporate governance (Muth and Donaldson, 1998). More specifically, our study has expanded 
the theoretical underpinning of corporate governance research by introducing the resource dependence theory to integrate the opposing arguments of the agency and stewardship perspectives. By examining the CEO duality issue in Sri Lanka, our study has also extended the theoretical applications of corporate governance to countries where governing mechanisms are largely incomplete.

\subsection{Theoretical Implications}

This study has significant implications for the agency and stewardship theories. The results indicate that CEO duality is favored under high board involvement, while nonduality is preferred when the CEO has family ties or board subcommittee appointments. Specifically, both the CEO's family involvement and participation in board subcommittees has a weakening effect on the duality-performance relationship. This finding supports the agency position by showing that duality is negatively associated with firm performance in situations where informal power also exists. Our finding also indicates that the separation of management and ownership is the key in current business. If a CEO holds too much power, either formally or informally, he/she is more likely to pursue individual interests, which will hurt firm performance. Thus, CEO appointments should be a strategic issue in family or non-family businesses, because they can greatly impact a firm's market value.

Conversely, a high level of board involvement contributes to the positive effect that CEO duality can have on firm performance, since the board is equipped to provide the resources required to advance firm value. As our study results indicate, in situations where board involvement is considerably high, the advantages of CEO 
duality outweigh non-duality, a finding that supports the study of Finkelstein and D'Aveni (1994) who found that board vigilance was positively associated with CEO duality. Specifically, when board members are proactively involved in strategic decision-making, agency abuses are reduced and agency costs minimized by the board's resource provisions.

These findings are interesting because resource dependence theory plays a major role in distinguishing between the benefits and concerns of both duality and nonduality. When the resource dependence theory is integrated only with the stewardship theory (hypotheses $1 b$ and $2 b$ ), the duality-performance relationship is adversely affected. However, when resource dependence theory is integrated with agency and stewardship theories (hypotheses 2 and 3), the duality-performance relationship is advanced. Thus, as the resource dependence perspective shows, providing resources to the firm through various avenues can benefit or hurt performance; the power attributions of executives hold the key. The performance implications of CEO duality can be examined by considering the relative power of the $\mathrm{CEO}$ and the power dynamics between the CEO and the board of directors.

\subsection{Practical Implications}

This study has also generated several implications that have relevance for practitioners. First, it should be noted that CEO duality or non-duality is not built into the CEO's official position. Therefore, it is unwise, and indeed impossible, to determine whether duality outperforms non-duality simply from a structural perspective. Whether to adopt duality or non-duality requires taking into account 
other types of power and resources that CEOs and boards may possess. Second, with respect to corporate board structure, a premium should be put on the resource provisions and involvement of the board so that increased firm performance can be achieved. Agency problems often occur when key decision makers other than the CEO have minimal or no financial interests or involvement in the consequences of their decisions (Boyd, 1995; Fama and Jensen, 1983). Finally, from the policy-making standpoint, internal corporate policies should be strengthened so that directors can be more involved in corporate decisions and actions.

Overall, the findings convey a clear warning to companies where CEO is equipped with additional informal power. As shown, economic performance of such companies is more likely to be negatively affected by such practices. Yet, how the board performs their fiduciary duties in these companies has a major implication on their long-term performance. Companies in Sri Lanka need to understand the power dynamics between $\mathrm{CEO}$ and board of directors to minimize negative consequences (see Uddin et al., 2017). This is particularly important as the ownership of most of the companies is concentrated as compared to that of companies in the western advanced economies.

\subsection{Limitations and Suggestions for Future Research}

This study uses a multitheoretical approach that makes use of the resource dependence theory to resolve the theoretical and empirical conflicts between the agency and stewardship perspectives. Such an integrated examination is beneficial 


\begin{abstract}
“because depending on just one single perspective is more likely to result in misleading conclusions about the structure as a whole" (Elsayesd, 2010, p. 80). However, the integration of these three theories does not reveal the whole scope of progress in corporate governance. Future research can advance the governance research by combining other points of view. For example, an integrated consideration of social network theory, stakeholder theory, and institutional theory may help resolve other controversial issues by identifying the boundary conditions that favor CEO duality or non-duality.
\end{abstract}

Secondly, care should be taken to interpret results presented in the study as it only reports a sample of 212 companies in one-year period. It is suggested that future studies may consider a relatively larger size of sample with multiple years as well as different measurements of variables. Thirdly, although the sample was collected from all publicly-listed companies in an Asian developing economy, which increases the applicability of corporate governance research, the generalization of findings requires that studies be conducted in other countries where managerial mechanisms and environments are similar to our study context. It may also be worthwhile to compare such applications between countries. Indeed, corporate governance research can be expanded by comparing different viewpoints in diverse institutional contexts (Aguilera et al., 2008).

Finally, as Bruton and Lau (2008) suggested, it is advisable to conduct a multilevel analysis rather than just a firm-level examination, since this will reveal the extent to which corporate governance applications vary in developed and developing 


\section{countries.}

In summary, an integrated analysis of the resource dependence, agency, and stewardship perspectives, which identifies the contexts where CEO duality can function well and where non-duality is preferred, has offered critical insights for a diverse range of research topics and business practices. Our study highlights board involvement as a facilitator and informal executive power as an inhibitor of the positive effects that CEO duality can have on firm market-based performance. 


\section{REFERENCES}

Adams, R., Almeida, H., and Ferreira, D. (2005), "Powerful CEOs and their impact on corporate performance", Review of Financial Studies, Vol. 18 No. 4, pp. 1403-1432.

Aguilera, R., Filatotchev, I., Gospel, H., and Jackson, G. (2008), “An organizational approach to comparative corporate governance: Costs, contingencies, and complementarities", Organization Science, Vol. 19 No. 3, pp. 475-492.

Ahmed, K., Hossain, M., and Adams, M. (2006), "The effects of board composition and board size on the informativeness of annual accounting earnings", Corporate Governance: An International Review, Vol. 14 No. 5, pp. 418-431.

Aiken, L. S., and West, S. G. (1991), Multiple Regression: Testing and Interpreting Interactions. Sage publications, Newbury Park: CA.

Aktas, N., Andreou, P. C., Karasamani, I., and Philip, D. (2018), "CEO duality, agency costs, and internal capital allocation efficiency", British Journal of Management. https://doi.org/10.1111/1467-8551.12277.

Anderson, R.C., Mansi, S.A. and Reeb, D.M. (2003), "Founding family ownership and the agency cost of debt", Journal of Financial Economics, Vol. 68 No. 2, pp. 263-285.

Anderson, R.C. and Reeb, D.M. (2003), "Founding-family ownership and firm performance: evidence from the S\&P 500", The Journal of Finance, Vol. 58 No. 3, pp. 1301-1328.

Anderson, R. C., and Reeb, D. M. (2004), "Board composition: Balancing family influence in S\&P 500 firms", Administrative Science Quarterly, Vol. 49 No. 2, pp. 209-237.

Azeez, A.A. (2015), “Corporate governance and firm performance: Evidence from Sri Lanka", Journal of Finance and Bank Management, Vol. 3 No. 1, pp. 180-189.

Baliga, B. R., Moyer, R. C., and Rao, R. S. (1996), "CEO duality and firm performance: What's the fuss?", Strategic Management Journal, Vol. 17 No. 1, pp. 41-53.

Barkema, H., and Pennings, J. (1998), “Top management pay: Impact of overt and covert power", Organization Studies, Vol. 19 No. 6, pp. 975-1003. 
Beavers, R. (2017), "CEO Long-Term Incentive Pay in Mergers and Acquisitions", Corporate Ownership and Control, Vol. 15, pp. 265-276.

Bennedsen, M., Nielsen, K.M., Pérez-González, F. and Wolfenzon, D. (2007), “Inside the family firm: The role of families in succession decisions and performance", The Quarterly Journal of Economics, Vol. 122 No. 2, pp. 647-691.

Benz, M., and Frey, B. S. (2007), "Corporate governance: What can we learn from public governance?", Academy of Management Review, Vol. 32 No. 1, pp. 92-104.

Berrone, P., and Gomez-Mejia, L. R. (2009), "Environmental performance and executive compensation: An integrated agency-institutional perspective", Academy of Management Journal, Vol. 52 No. 1, pp. 103-126.

Boyd, B. (1995), "CEO duality and firm performance: A contingency model", Strategic Management Journal, Vol. 16 No. 4, pp. 301-312.

Bruton, G. D., and Lau, C.-M. (2008), "Asian management research: Status today and future outlook", Journal of Management Studies, Vol. 45 No. 3, pp. 636-659.

Chahine, S., and Tohmé, N. S. (2009), “Is CEO duality always negative? An exploration of CEO duality and ownership structure in the Arab IPO context", Corporate Governance: An International Review, Vol. 17 No. 2, pp. 123-141.

Chrisman, J. (2019), "Stewardship theory: realism, relevance, and family firm governance", Entrepreneurship Theory and Practice, In Press, DOI: $10.1177 / 1042258719838472$

Colombo Stock Exchange. (2008). Fact Book - 2008. Colombo.

Colombo Stock Exchange. (2009). Data Library - 2009. Colombo.

Corbetta, G., and Salvato, C. (2004), "Self-serving or self-actualizing? Models of man and agency costs in different types of family firms: A commentary on "comparing the agency costs of family and non-family firms: Conceptual issues and exploratory evidence". Entrepreneurship: Theory and Practice, Vol. 28 No. 4, pp. 355-363. 
Daily, C., and Dalton, D. (1992), “The relationship between governance structure and corporate performance in entrepreneurial firms", Journal of Business Venturing, Vol. 7, No. 5, pp. 375-386.

Daily, C., Dalton, D., and Cannella Jr, A. (2003), “Corporate governance: Decades of dialogue and data", Academy of Management Review, Vol. 28 No. 3, pp. 371-382.

Dalton, D., Daily, C., Certo, S., and Roengpitya, R. (2003), "Meta-analyses of financial performance and equity: fusion or confusion?", Academy of Management Journal, Vol. 46 No. 1, pp. 13-26.

Dalton, D., Daily, C., Johnson, J., and Ellstrand, A. (1999), “Number of directors and financial performance: A meta-analysis", Academy of Management Journal, Vol. 42 No. 6, pp. 674-686.

Davis, J., Schoorman, F., and Donaldson, L. (1997), "Toward a stewardship theory of management", Academy of Management Review, Vol. 22 No. 1, pp. 20-47.

Dharmadasa, P., Gamage, P., and Herath, S. K. (2014), “Corporate governance, board characteristics and firm performance: Evidence from Sri Lanka", Journal of South Asian Development, Vol. 21 No. 1, pp. 7-31.

Donaldson, L., and Davis, J. (1991), "Stewardship theory or agency theory: CEO governance and shareholder returns", Australian Journal of Management, Vol. 16 No. 1, pp. $49-64$.

Duru, A., Iyengar, R. J., and Zampelli, E. M. (2016), “The dynamic relationship between CEO duality and firm performance: The moderating role of board independence", Journal of Business Research, Vol. 69 No. 10, pp. 4269-4277.

Eddleston, K., and Kellermanns, F. (2007), "Destructive and productive family relationships: A stewardship theory perspective", Journal of Business Venturing, Vol. 22 No. 4, pp. 545-565.

Ees, H. v., Gabrielsson, J., and Huse, M. (2009), “Toward a behavioral theory of boards and corporate governance", Corporate Governance: An International Review, Vol. 17 No. 3, pp. 307-319. 
Ekanayake, A. (2011), The role of accounting in corporate governance of banks in a developing country: Evidence from Sri Lanka, Unpublished PhD thesis, Macquarie University, Sydney.

Elsayed, K. (2007), “Does CEO duality really affect corporate performance?”, Corporate Governance: An International Review, Vol. 15 No. 6, pp. 1203-1214.

Elsayed, K. (2010), "A multi theory perspective of board leadership structure", British Journal of Management, Vol. 21 No. 1, pp. 80-99.

Fama, E., and Jensen, M. (1983), "Separation of ownership and control", The Journal of Law and Economics, Vol. 26 No. 2, pp. 301-325.

Ferris, S. P., Jagannathan, M., and Pritchard, A. C. (2003), “Too busy to mind the business? Monitoring by directors with multiple board appointments", The Journal of Finance, Vol. 58 No. 3, pp. 1087-1111.

Finkelstein, S. (1992). Power in top management teams: dimensions, measurements, and validation. Academy of Management Journal, Vol. 35 No. 3, pp. 505-538.

Finkelstein, S., and D'Aveni, R. A. (1994), "CEO duality as a double-edged sword: How boards of directors balance entrenchment avoidance and unity of command", Academy of Management Journal, Vol. 37 No. 5, pp. 1079-1108.

Finkelstein, S., and Hambrick, D. (1989), "Chief executive compensation: A study of the intersection of markets and political processes", Strategic Management Journal, Vol. 10 No. 2, pp. 121-134.

Gillan, S. L. (2006), "Recent developments in corporate governance: An overview", Journal of Corporate Finance, Vol. 12, pp. 381-402.

Gillan, S. L., and Martin, J. D. (2007), "Corporate governance post-Enron: Effective reforms, or closing the stable door?", Journal of Corporate Finance, Vol. 13 No. 5, 929958.

Greve, H., and Mitsuhashi, H. (2007), "Power and glory: Concentrated power in top management teams", Organization Studies, Vol. 28 No. 8, pp. 1197-1221. 
Harris, D., and Helfat, C. E. (1998), “CEO duality, succession, capabilities and agency theory: Commentary and research agenda", Strategic Management Journal, Vol. 19 No. 9, 901-904.

Harris, I., and Shimizu, K. (2004), "Too busy to serve? An examination of the influence of overboarded directors", Journal of Management Studies, Vol. 41 No. 5, pp. 775-798.

Henry, D. (2009), “Agency costs, ownership structure and corporate governance compliance: A private contracting perspective", Pacific-Basin Finance Journal, Vol. 18 No. 1, pp. 24-46.

Hillman, A. J., and Dalziel, T. (2003), "Boards of directors and firm performance: Integrating agency and resource dependence perspectives", Academy of Management Review, Vol. 28 No. 3, pp. 383-396.

Hillman, A. J., Withers, M. C., and Collins, B. J. (2009), "Resource dependence theory: A review", Journal of Management, Vol. 35 No. 6, pp. 1404-1427.

Holm, C., and Schøler, F. (2010), "Reduction of asymmetric information through corporate governance mechanisms - the importance of ownership dispersion and exposure toward the international capital market", Corporate Governance: An International Review, Vol. 18 No. 1, pp. 32-47.

Hoskisson, R., Hitt, M., Johnson, R., and Grossman, W. (2002), “Conflicting voices: The effects of institutional ownership heterogeneity and internal governance on corporate innovation strategies", Academy of Management Journal, Vol. 45 No. 4, pp. 697-716.

Iyengar, R. J., and Zampelli, E. M. (2009), "Self-selection, endogeneity, and the relationship between CEO duality and firm performance", Strategic Management Journal, Vol. 30 No. 10, pp. 1092-1112.

Jackling, B., and Johl, S. (2009), "Board structure and firm performance: Evidence from India's top companies", Corporate Governance: An International Review, Vol. 17 No. 4, pp. 492-509.

Jaggi, T., and Gul, F. (2001), "CEO domination, growth opportunities, and their impact on audit fees", Journal of Accounting, Auditing and Finance, Vol. 16 No. 3, pp. 189208. 
Jensen, M. C. (1993), "Modern industrial revolution, exit, and the failure of internal control systems", Journal of Finance, Vol. July, pp. 831-880.

Kim, K.-H., Al-Shammari, H. A., Kim, B., and Lee, S.-H. (2009), “CEO duality leadership and corporate diversification behavior", Journal of Business Research, Vol. 62 No. 11, pp. 1173-1180.

Krause, R., Priem, R., and Love, L. (2015), “Who's in charge here? Co-CEOs, power gaps, and firm performance", Strategic Management Journal, Vol. 36 No. 13, pp. 20992110.

Krause, R., Semadeni, M., and Withers, M. C. (2016), "That special someone: When the board views its chair as a resource", Strategic Management Journal, Vol. 37 No. 9, pp. 1990-2002.

Krause, R., Semadeni, M., and Cannella Jr, A. A. (2014), “CEO duality: A review and research agenda", Journal of Management, Vol. 40 No. 1, pp. 256-286.

Kroll, M., Walters, B. A., and Wright, P. (2008), “Board vigilance, director experience, and corporate outcomes", Strategic Management Journal, Vol. 29 No. 4, pp. 363-382.

Lasfer, M. (2006), "The interrelationship between managerial ownership and board structure", Journal of Business Finance and Accounting, Vol. 33 No. 7-8, pp. 10061033.

Lin, H.-C., and Shih, C.-T. (2008), "How executive SHRM system links to firm performance: The perspectives of upper echelon and competitive dynamics", Journal of Management, Vol. 34 No. 5, pp. 853-881.

Lynall, M. D., Golden, B. R., and Hillman, A. J. (2003), “Board composition from adolescence to maturity: A multitheoretic view", Academy of Management Review, Vol. 28 No. 3, pp. 416-431.

Masulis, R.W. and Mobbs, S. (2011), "Are all inside directors the same? Evidence from the external directorship market", The Journal of Finance, Vol. 66 No. 3, pp. 823-872. 
Masulis, R.W. and Mobbs, S. (2014), “Independent director incentives: Where do talented directors spend their limited time and energy?", Journal of Financial Economics, Vol. 111 No. 2, pp. 406-429.

Matta, E., and Beamish, P. W. (2008), "The accentuated CEO career horizon problem: Evidence from international acquisitions", Strategic Management Journal, Vol. 29 No. 7, pp. 683-700.

McCarthy, D. J., and Puffer, S. M. (2008), "Interpreting the ethicality of corporate governance decisions in Russia: Utilizing integrative social contracts theory to evaluate the relevance of agency theory norms", Academy of Management Review, Vol. 33 No. 1, pp. 11-31.

McDonald, M. L., and Westphal, J. D. (2010), “A little help here? board control, CEO identification with corporate elite, and strategic help provided to CEOs at other firms", Academy of Management Journal, Vol. 53 No. 2, pp. 343-370.

Mooney, C. H., Dalton, D. R., Dalton, C. M., and Certo, S. T. (2007), “CEO succession as a funnel: The critical, and changing, role of inside directors", Organizational Dynamics, Vol. 36 No. 4, pp. 418-428.

Muth, M., and Donaldson, L. (1998), "Stewardship theory and board structure: A contingency approach", Corporate Governance: An International Review, Vol. 6 No. 1, pp. 5-28.

Peiro, J., and Melia, J. (2003), “Formal and informal interpersonal power in organisations: Testing a bifactorial model of power in role-sets", Applied Psychology, Vol. 52 No. 1, pp. 14-35.

Puffer, S. M., and Weintrop, J. B. (1995), “CEO and board leadership: The influence of organizational performance, board composition, and retirement on CEO successor origin", The Leadership Quarterly, Vol. 6 No. 1, pp. 49-68.

Reeb, D., and Upadhyay, A. (2010), "Subordinate board structures", Journal of Corporate Finance, Vol. 16 No. 4, pp. 469-486.

Shleifer, A., and Vishny, R. (1997), "A survey of corporate governance”, Journal of Finance, Vol. 52 No. 2, pp. 737-783. 
Smith, K. G., Smith, K. A., Olian, J. D., Sims, H. P., O’Bannon, D. P., and Scully, J. A. (1994), "Top management team demography and process: The role of social integration and communication", Administrative Science Quarterly, Vol. 39 No. 3, pp. 412-438.

Sundaramurthy, C., and Lewis, M. (2003), "Control and collaboration: Paradoxes of governance", Academy of Management Review, Vol. 28 No. 3, pp. 397-415.

Vafeas, N. (1999), "Board meeting frequency and firm performance", Journal of Financial Economics, Vol. 53 No. 1, pp. 113-142.

Van Thiel, S. (2016), A principal-agent perspective. In Van de Walle, S. and Groeneveld, S. (Eds), Theory and Practice of Public Sector Reform (Routledge).

Villalonga, B. and Amit, R. (2006), "How do family ownership, control and management affect firm value?", Journal of financial Economics, Vol. 80 No. 2, pp. 385-417.

Uddin, S., Jayasinghe, K., and Ahmed, S. (2017), "Scandals from an island: Testing AngloAmerican corporate governance frameworks", Critical Perspectives on International Business, Vol. 13 No. 4, pp. 349-370.

Wijethilake, C., Ekanayake, A., and Perera, S. (2015), "Board involvement in corporate performance: evidence from a developing country", Journal of Accounting in emerging economies, Vol. 5 No. 3, pp. 250-268.

Worrell, D., Nemec, C., and Davidson III, W. (1998), "One hat too many: Key executive plurality and shareholder wealth", Strategic Management Journal, Vol. 18 No. 6, pp. 499-507.

Yang, T., and Zhao, S. (2014), "CEO duality and firm performance: Evidence from an exogenous shock to the competitive environment", Journal of Banking $\mathcal{E}$ Finance, Vol 49, pp. 534-552.

Zajac, E., and Westphal, J. (1996), "Who shall succeed? How CEO/board preferences and power affect the choice of new CEOs", Academy of Management Journal, Vol. 39 No. 1, pp. 64-90. 
Social Responsibility Journal

Page 42 of 51

$$
\begin{aligned}
& 1 \\
& 2 \\
& 3 \\
& 4 \\
& 5 \\
& 6 \\
& 7 \\
& 8 \\
& 9 \\
& 10 \\
& 11 \\
& 12 \\
& 13 \\
& 14 \\
& 15 \\
& 16 \\
& 17 \\
& 18 \\
& 19 \\
& 20 \\
& 21 \\
& 22 \\
& 23 \\
& 24 \\
& 25 \\
& 26 \\
& 27 \\
& 28 \\
& 29 \\
& 30 \\
& 31 \\
& 32 \\
& 33 \\
& 34 \\
& 35 \\
& 36 \\
& 37 \\
& 38 \\
& 39 \\
& 40 \\
& 41 \\
& 42 \\
& 43 \\
& 44 \\
& 45 \\
& 46 \\
& 47 \\
& 48 \\
& 49 \\
& 50 \\
& 51 \\
& 52 \\
& 53 \\
& 54 \\
& 55 \\
& 56 \\
& 57 \\
& 59
\end{aligned}
$$




\section{TABLE 1}

Descriptive Information of Study Sample

\begin{tabular}{|c|c|c|c|c|c|}
\hline \multirow{2}{*}{ Industry Segments } & \multicolumn{2}{|c|}{ Firms } & \multirow{2}{*}{$\begin{array}{c}\text { Market } \\
\text { Capitalization }\end{array}$} & \multirow{2}{*}{$\begin{array}{c}\text { Market } \\
\text { Turnover } \\
\text { Rate } \\
\end{array}$} & \multirow{2}{*}{$\begin{array}{c}\text { CEO } \\
\text { Duality } \\
(\%)\end{array}$} \\
\hline & Total & Sample & & & \\
\hline Trading & 9 & 7 & 1.0 & 22.27 & 63 \\
\hline Hotels and Travels & 32 & 28 & 7.4 & 12.59 & 53 \\
\hline Plantations & 18 & 18 & 2.3 & 20.79 & 44 \\
\hline Services & 6 & 5 & 0.3 & 3.86 & 80 \\
\hline Banking and Finance & 33 & 31 & 16.8 & 9.00 & 13 \\
\hline Diversified holdings & 13 & 12 & 15.7 & 10.87 & 58 \\
\hline $\begin{array}{l}\text { Beverage Food and } \\
\text { Tobacco }\end{array}$ & 18 & 17 & 12.4 & 8.25 & 41 \\
\hline $\begin{array}{l}\text { Chemicals and } \\
\text { Pharmaceuticals }\end{array}$ & 9 & 9 & 1.1 & 34.41 & 33 \\
\hline $\begin{array}{ll}\text { Constructions } & \text { and } \\
\text { Engineering } & \end{array}$ & 2 & 3 & 0.8 & 15.06 & 67 \\
\hline Footwear and Textiles & 3 & 23 & 0.5 & 10.40 & 0 \\
\hline Health care & 6 & 6 & 2.7 & 3.23 & 50 \\
\hline Information Technology & 1 & 1 & 0.1 & 56.91 & 0 \\
\hline Investment Trusts & 7 & 6 & $0^{\circ}$ & 11.46 & 83 \\
\hline Land and Property & 20 & 18 & 20 & 15.12 & 52 \\
\hline Manufacturing & 32 & 28 & 6.9 & 17.79 & 32 \\
\hline Motors & 6 & 6 & 2.7 & 85.66 & 33 \\
\hline Oil Palms & 5 & 5 & 2.5 & 3.40 & 100 \\
\hline Power and Energy & 3 & 3 & 2.3 & 15.87 & 0 \\
\hline Stores Suppliers & 5 & 5 & 0.5 & 7.75 & 40 \\
\hline Telecommunication & 2 & 2 & 21.4 & 28.81 & 0 \\
\hline Total/Average & 231 & 212 & $5 \%$ & $19.68 \%$ & $43 \%$ \\
\hline
\end{tabular}




\section{TABLE 2}

\section{Means, Standard Deviations, and Correlations}

\begin{tabular}{|c|c|c|c|c|c|c|c|c|c|c|c|c|c|c|c|c|c|c|c|c|c|c|}
\hline Variables & Mean & SD & 1 & 2 & 3 & 4 & 5 & 6 & 7 & 8 & 9 & 10 & 11 & 12 & 13 & 14 & 15 & 16 & 17 & 18 & 19 & 20 \\
\hline 1. Earning Per Share $(08 / 09)$ & 6.15 & 19.13 & 1 & & & & & & & & & & & & & & & & & & & \\
\hline 2. Earning Per Share $(07 / 08)$ & 7.19 & 13.46 & .51 & 1 & & & & & & & & & & & & & & & & & & \\
\hline 3. CEO Duality & .44 & .50 & .06 & -.09 & 1 & & & & & & & & & & & & & & & & & \\
\hline 4. CEO - Family Ties & .52 & .50 & .01 & -.13 & .76 & 1 & & & & & & & & & & & & & & & & \\
\hline 5. CEO - Committee Participation & .43 & .50 & -.03 & .04 & .10 & -.04 & 1 & & & & & & & & & & & & & & & \\
\hline 6. Board Shareholdings & 10.46 & 20.13 & .12 & .05 & -.09 & .06 & -.06 & 1 & & & & & & & & & & & & & & \\
\hline 7. Freq. of Board Meetings & 6.82 & 3.27 & .13 & .17 & -.21 & -.17 & .11 & .14 & 1 & & & & & & & & & & & & & \\
\hline 8. CEO Tenure & 2.05 & .95 & .07 & .18 & .07 & .14 & .03 & .10 & -.05 & 1 & & & & & & & & & & & & \\
\hline 9. \# of Executive Directors & 2.76 & 1.68 & .01 & .14 & .06 & .13 & -.08 & .14 & .05 & .06 & 1 & & & & & & & & & & & \\
\hline 10. \# of Non-Executive Directors & 4.99 & 2.26 & -.09 & .04 & -.24 & -.18 & -.05 & .11 & .29 & -.09 & -.39 & 1 & & & & & & & & & & \\
\hline 11. \# of Independent Directors & 2.61 & 1.40 & .04 & .02 & -.18 & -.12 & -.02 & -.02 & .30 & -.15 & .07 & .53 & 1 & & & & & & & & & \\
\hline 12. \# of Board Committees & 1.58 & .85 & .15 & .17 & -.17 & -.14 & -.14 & .11 & .19 & .00 & .03 & .40 & .46 & 1 & & & & & & & & \\
\hline 13. Executive Team Size & 15.10 & 7.99 & .12 & .11 & -.12 & -.16 & .09 & -.03 & .34 & .11 & .05 & .18 & .21 & .15 & 1 & & & & & & & \\
\hline 14. Chairman Busyness & .50 & .501 & -.02 & -.14 & -.03 & -.08 & .47 & -.05 & .14 & .02 & -.11 & -.06 & .01 & -.04 & .18 & 1 & & & & & & \\
\hline 15. Firm Age & 3.40 & .62 & .16 & .13 & .13 & .17 & .04 & .07 & -.04 & .16 & .10 & -.20 & .02 & .06 & .07 & .09 & 1 & & & & & \\
\hline 16. Firm Size & 7.49 & 1.16 & .01 & .23 & -.34 & -.28 & .03 & -.07 & .25 & -.09 & .06 & .34 & .26 & .30 & .19 & -.06 & -.14 & 1 & & & & \\
\hline 17. Current Ratio & 3.64 & 9.73 & .16 & -.05 & .19 & .16 & .02 & -.10 & -.17 & -.01 & -.05 & -.20 & -.06 & -.08 & -.07 & .01 & .14 & -.24 & 1 & & & \\
\hline 18. Debt Ratio & 147.73 & 376.79 & -.19 & .11 & -.14 & -.24 & .16 & -.04 & .38 & -.05 & -.01 & .23 & .11 & .10 & .33 & .02 & -.05 & .21 & -.05 & 1 & & \\
\hline 19. Industry - Manufacturing & .19 & .39 & -.04 & -.08 & .08 & .11 & .20 & .07 & .27 & .06 & -.15 & .16 & .15 & -.03 & .18 & .21 & .09 & -.28 & .10 & .20 & 1 & \\
\hline 20. Industry - Service & .61 & .49 & -.02 & .06 & .06 & .01 & -.08 & -.11 & -.24 & -.09 & .16 & -.15 & -.13 & -.09 & -.15 & -.27 & -.02 & .24 & -.03 & -.09 & -.61 & 1 \\
\hline
\end{tabular}

$\mathrm{n}=2$ 212. Standardized correlation coefficients $\geq .14$ in the table were significant at $\mathrm{p}<.05$. (2-tailed) 


\section{TABLE 3}

\section{Results of Regression Analyses}

\begin{tabular}{|c|c|c|c|c|c|}
\hline Variables & & Model 1 & Model 2 & Model 3 & Model 4 \\
\hline \multirow[t]{14}{*}{ Control } & CEO tenure & -.044 & -.047 & -.033 & -.007 \\
\hline & \# of Executive directors & $-.153^{*}$ & $-.158^{*}$ & $-.224^{* *}$ & $-.264^{* * *}$ \\
\hline & \# of Non-executive directors & $-.215^{*}$ & $-.214^{*}$ & $-.288^{* * *}$ & $-.320^{* * *}$ \\
\hline & \# of Independent directors & .085 & .091 & .118 & $.146+$ \\
\hline & \# of Board subcommittees & .113 & .113 & .089 & .077 \\
\hline & Executive team size & $.180^{* *}$ & $181^{* *}$ & $.157^{*}$ & $.160^{*}$ \\
\hline & Chairman busyness & -.030 & -.011 & -.002 & .090 \\
\hline & Firm age (log) & .031 & .026 & .018 & .018 \\
\hline & Firm size (log) & -.032 & .013 & .001 & -.041 \\
\hline & Past firm performance(log) & $.502^{* * *}$ & $.507^{* * *}$ & $.491^{* * *}$ & $.448^{* * *}$ \\
\hline & Current ratio & $.143^{*}$ & $.136^{*}$ & $.163^{* *}$ & $.201^{* * *}$ \\
\hline & Debt ratio & $-.278^{* * *}$ & $-.273^{* * *}$ & $-.303^{* * *}$ & $-.299 * * *$ \\
\hline & Industry - manufacturing & -.067 & -.080 & -.041 & -.013 \\
\hline & Industry - service & -.032 & -.043 & -.061 & -.068 \\
\hline Independent & CEO duality & & .075 & $.183^{*}$ & $.294^{* *}$ \\
\hline \multirow[t]{4}{*}{ Moderating } & CEO - family ties & & & -.094 & -.150 \\
\hline & CEO - subcommittee participation & & & -.055 & -.080 \\
\hline & Boards' shareholdings & & & $.163^{* *}$ & $.194^{* *}$ \\
\hline & Freq. of board meetings & & & $.188^{* *}$ & $250^{* * *}$ \\
\hline \multirow[t]{4}{*}{ Interaction } & CEO duality x CEO - family ties & & & & $-.139^{*}$ \\
\hline & $\begin{array}{l}\text { CEO duality x CEO - subcommittee } \\
\text { participation }\end{array}$ & & & & $-.141^{*}$ \\
\hline & CEO duality $x$ board shareholdings & & & & $.128^{*}$ \\
\hline & $\begin{array}{l}\text { CEO duality } x \text { freq. of board } \\
\text { meetings }\end{array}$ & & & & $.133+$ \\
\hline $\mathrm{R}^{2}$ & & 37.1 & 37.6 & 42.9 & 47.4 \\
\hline Adjusted $\mathrm{R}^{2}$ & & 32.6 & 32.8 & 37.2 & 41.0 \\
\hline $\mathrm{F}$ & & $8.30^{* * *}$ & $7.86^{* * *}$ & $7.59^{* * *}$ & $7.37^{* * *}$ \\
\hline$\Delta \mathrm{R}^{2}$ & & .371 & .005 & .053 & .045 \\
\hline $\mathrm{F}$ for $\Delta \mathrm{R}^{2}$ & & $8.30^{* * *}$ & 1.43 & $4.50^{* *}$ & $4.05^{* *}$ \\
\hline
\end{tabular}

$\mathrm{n}=212$. Standardized coefficients are reported.

$+\mathrm{p}<.10,{ }^{*} \mathrm{p}<.05,{ }^{* *} \mathrm{p}<.01,{ }^{* * *} \mathrm{p}<.001$ 


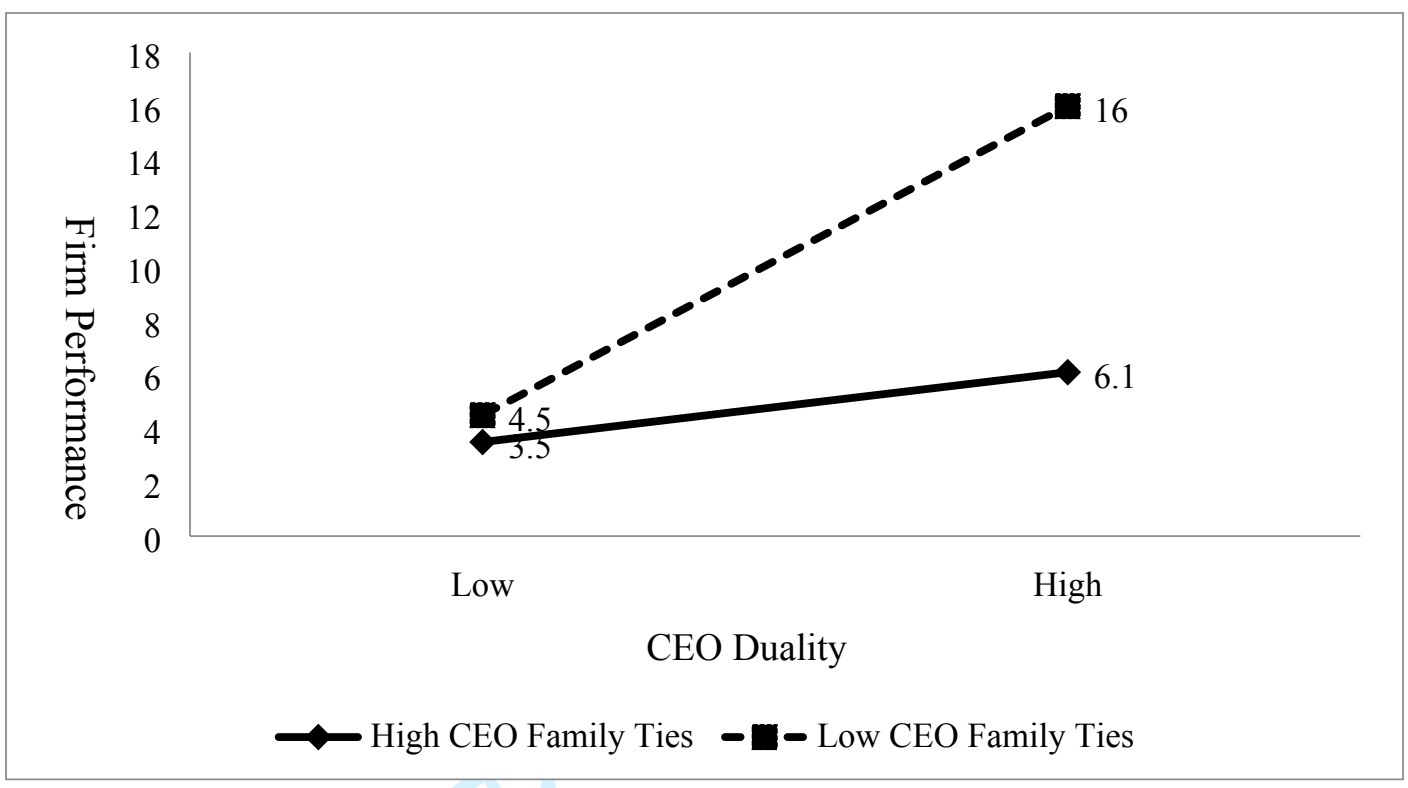

FIGURE 1

Two-way interaction between CEO duality and CEO family ties on firm performance

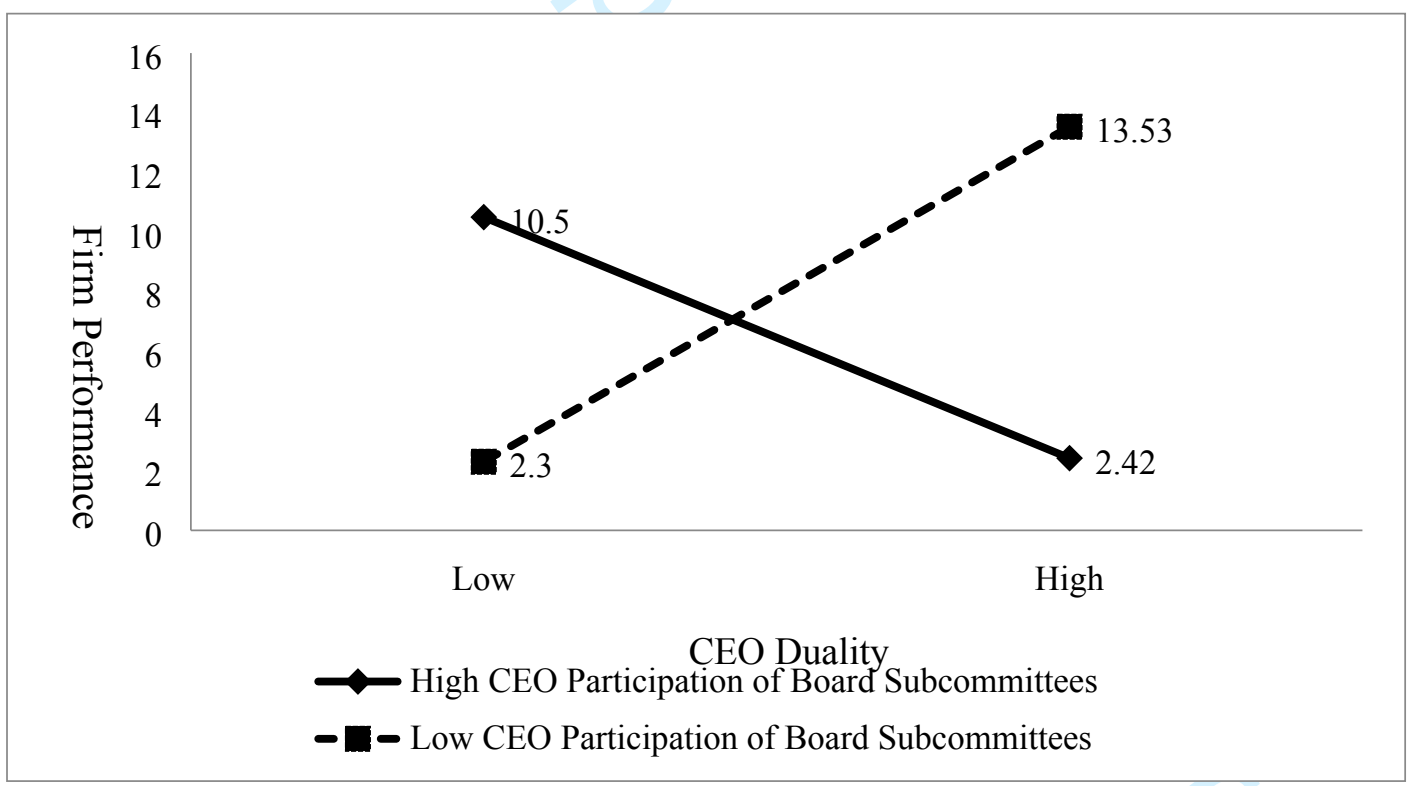

FIGURE 2

Two-way interaction between CEO duality and CEO participation in board subcommittees on firm performance 


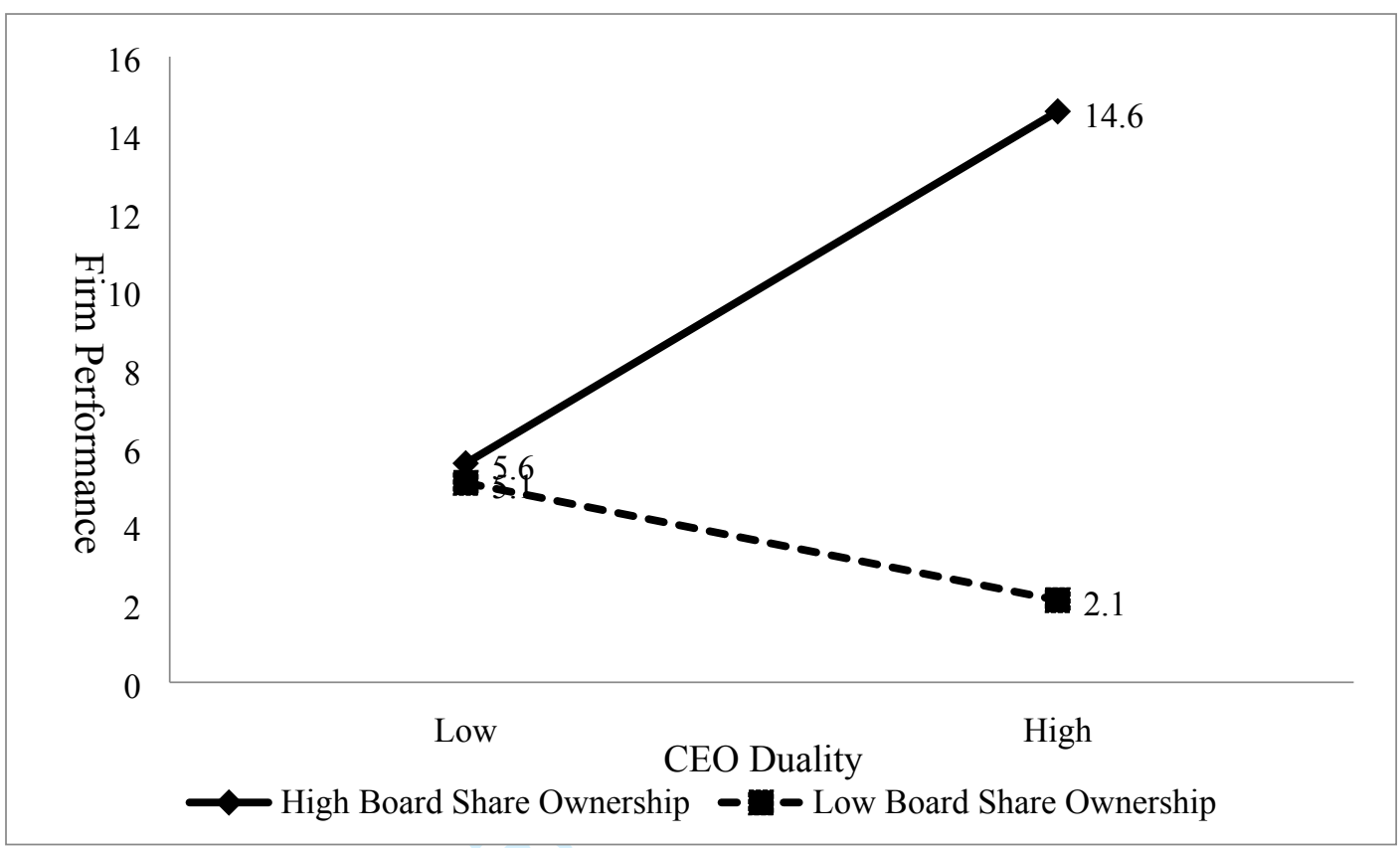

FIGURE 3

Two-way interaction between CEO duality and board shareholdings on firm performance

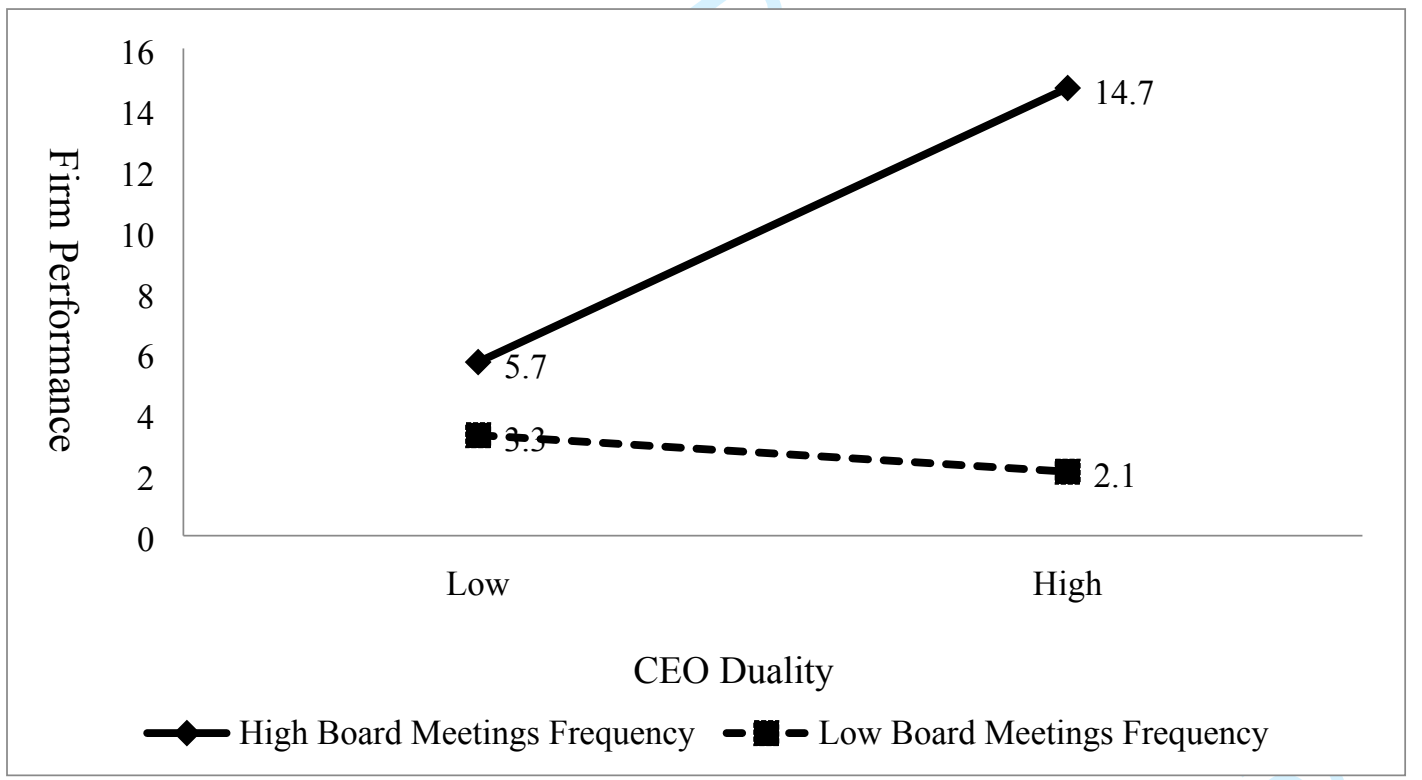

FIGURE 4

Two-way interaction between CEO duality and board meetings frequency on firm performance 